UDK 94:327(436-89:497.115)"190”

94(497.115-89)"190"

94:323.1(=18)(497.115-89)"190"

doi: $10.5937 /$ bastina30-25462

Originalni naučni rad

Vesna S. ZARKOVIĆ*

Institute for Serbian Culture - Prishtina / Leposavić

\title{
FANDAS AND OPERATION OF THE AUSTRIA-HUNGARY IN PRIZREN AND PEĆ SANJAK (1900-1905)**
}

\begin{abstract}
The author points out the Austro-Hungarian influence on the Catholic Albanians- fandas in Prizren and Peć sanjak in the early 20th century. Austro-Hungarian activity in this field intensified after the Serbo-Turkish wars and the Congress of Berlin. Violence against the Serbian population had since become more frequent, aided by the fandas that have the support and protection of Roman Catholic priests and Austro-Hungarian diplomats. The Catholic Albanian people commit various forms of zulum over Serbian people, who powerless before them abandoned their properties. A large number of Serbian properties were getting new owners -fandas, that were settled with the permission of the beys. The Austria-Hungary, wishing to cause as much disorder as possible, incited the fandas and Mohammedan Albanian people against the Serbian people, in whom they saw the main obstacle to the achievement of their aims and the occupation of these regions. The situation demanded greater involvement of Serbian and Russian diplomacy in protecting the thinned-out Serbian population in Peć and Prizren sanjak.
\end{abstract}

Key words: Serbian people, Albanian people, fandas, Austria-Hungary, Peć sanjak, Prizren sanjak

The Serbian population who lived in the area of Old Serbia in the late 19th and early 20th century found themselves in an unenviable position. This was mostly due to inequality in front of the institutions of the Ottoman state, but also to the unique attitude of Albanian people, who saw the main culprits for all the troubles in Serbians. Although almost without exception, they acted homogeneously towards the Serbian people, the Albanian people were significantly divided within their community, which affected their affirmation as nation. Of the many divisions, tribal, political and religious are the most significant ones.

* Senior scientific associate, vesna.zarkovic07@gmail.com

** This paper is written in the scope of the project Material and Spiritual Culture of Kosovo and Metohija (Record no. 178028), which was approved and financed by the Ministry of Education, Science and Technological Development, Republic of Serbia. 
These divisions also affected frequent mutual killings, linked to respect of customary law, and led to small wars of belligerent families, involving entire tribes.

One of the important divisions in Albanians society is the religious one: on Muslims and Christians, subdivided on Orthodox and Roman Catholics. However, Orthodox Albanians were only present in southern Albania today, and the documents are not recorded in Old Serbia. In contrast, Roman Catholic Albanians were mostly in the Metohija area, where they are called fandas.

Their origin and presence in the territory of Kosovo and Metohija is not the clearest, to which the processes of migration and islamization, which are interconnected, contribute. Certainly, the homeland of the fandas should be sought in the north of present-day Albania, where they are still in considerable numbers. Miranda Vickers states that the fandas in Kosovo and Metohija come from the upper reaches of the Fan and Fandit rivers. ${ }^{1}$ According to the report by British Intelligence Service from the First World War, Muslim tribesmen were intolerant of the fandas because they feared them for persisting in revenge (Vickers 1998: 42).

Because of their courage, the Turkish aghas and beys gladly received them and settled them on their properties, seeing in them protection from the local Albanian (Muslim) population. Branislav Nušić believes that the fandas began to settle in Metohija in the early 19th century, in search of a fertile land. Their predecessor was the Kabash tribe, which settled in the vicinity of Prizren, above the Monastery of St. Marko. After coming to them in the vicinity of Prizren, the fandas suppressed the Serbian villages of Grahovec and Stratovec (Mikić 1988: 28).

Nušić recorded this information at the end of the 19th century while traveling from Prishtina to the Adriatic Sea. However, data from Vatican archives record the presence of Roman Catholics during the first half of the eighteenth century, after the great migration of Serbs, in Prizren, Djakovica and Peć districts. The documents noted by name the villages in Metohija inhabited by Roman Catholics (Šešum 2017: 31). Since these villages later were not Roman Catholics', it is believed that the population was from the Kliment tribe, who, due to their active participation with the Austrian army, were forcibly settled on the properties of Serbs, who had been displaced during the Great Migration (Šešum 2017: 31). Over time, the number of Roman Catholics decreased due to further migration to the west, as well as to the conversion to Islam. The Roman Catholic population, as well as the Orthodox, was exposed to the conversion, but to a much lesser extent, because they had protection in the fises ${ }^{2}$ and in the organization of the Roman Catholic Church. In spite of this, the conversion of the fandas to Islam was recorded. For some it was permanent, while for others it was a form of mimicry. In order to protect themselves, they professed Islam

1 In present-day north Albania there is a place called Fan, in Lezhë County, settled by Roman Catholic population. There is a church dedicated to St. Marko in this settlement.

2 Fis is an Albanian term for tribe. 
publicly and still were Roman Catholics at home. The presence of these dualfaith or crypto-Catholics ${ }^{3}$ was reported more in the villages of Kosovo's Pomoravlje, in a territory where the fanda community was much smaller than in Metohija. Although this phenomenon is mainly related to Albanian people, it is also present at Roman Catholics of Slovenian origin that lived in Janjevo and Letnička Župa (Urošević 2001: 83-92; Urošević 2001a: 181-183).

A new influx of northern Albania fandas occurred after the Serbian-Turkish wars (1876-1878) and the Congress of Berlin (1878) and is linked to Serb migrations and increased Austro-Hungarian agitation. As early as the 1880 s, during the Prizren League (1878-1881), there was a great migration of the Serbian people (Hrabak 1998). Although directly blamed, the Austro-Hungarians denied their founding role and blamed the United Kingdom, whose consul was in Prizren throughout the League's session. During the Prizren League and after the migration of Serbs, many properties remained abandoned. Albanian beys were settling on them Roman Catholic Albanians - fandas, who became the main support in the spread of Austro-Hungarian propaganda. With the increase in the number of fandas, Roman Catholic schools were opened, whose attendees influenced the further spread of propaganda (Kosovo and Metohija in Serbian history 1989: 256).

The territory of Old Serbia and the Albanian people were of particular importance to the political and military circles of Austria-Hungary. In Vienna, they anticipated the rapid dissolution of the Ottoman Empire and were preparing to take on the role of mandatar and establish their own power, on the same principle as in Bosnia and Herzegovina. That is why Count Goluhovski, the Minister of Foreign Affairs of Austria-Hungary, considered it crucial that the Albanian people not fall under foreign influence (Kosovo and Metohija in Serbian History 1989: 257).

Austro-Hungarian work on the terrain soon began to produce results. Already at the beginning of 1899 at a gathering in Peć, a group of Albanian leaders, sympathetic to Austro-Hungary, represented a significant group, in addition to the already existing Turkophiles and autonomists. A group of tribal and feudal lords, including earlier Sultan favorites, advocated moving closer to Austria-Hungary, presenting it as a potential protector of Albanian people from neighboring Serbian countries. The number of Austro-Hungarian supporters was increasing, thanks to the money used by the Austro-Hungarian intelligence agencies to bribe more prominent Albanians. Russia’s newspaper „Novoe vremya"reported that between five and six million crowns was allocated annually for propaganda among Albanian people from the Dual Monarchy's budget (Stojančević 1994: 262).

3 The Albanians call them the Ljarmani. According to the story circulating among them "their father and grandfather were Turks, and the rest is 'ljarm' (colorful-mixed)", hence the name. See the next note. 
The Austria-Hungary worked on spreading propaganda in several directions among the Albanians people. In Metohija, where representatives of some fises were competing for dominance, spies were being inserted, and there was a spread of propaganda by Muslim religious leaders from Bosnia. Roman Catholic friars spread stories among Albanians of the Muslim faith that Serbia and Montenegro were exponents of Russian politics in the Balkans and that AustriaHungary was their only friend. Along with such work, some Viennese newspapers, announcing some events from Old Serbia, addressed them as coming from Albania. In this way, they wanted to create the impression that the Albanians in Kosovo Vilayet represented the majority, or that there were almost no Serbs in that area (Bataković 1984: 256-257).

On the situation in the Ottoman Empire, whose authorities began to lose their authority, was greatly affected by the uprising in Herzegovina and the Serbo-Turkish wars. This situation went in favor to Albanian people, who started increasingly arming themselves since then. ${ }^{4}$ All the anger and hatred was directed against the Serbian people, who began to abandon their properties and move to Serbia, Bulgaria and Valachia. In this emigration, the population of Peć, Vučitrn and Gnjilane regions prevailed. Soon, the emigrated Serbs, especially in the Peć sanjak, were replaced by Roman Catholics - fandas, somewhat worse than the local Albanians. The Fandas had the support of Latin friars who were also trying to win over the Orthodox with their skill. Although the Serbian people were loyal to the Orthodox faith and tradition, there was a danger, especially among the ignorant, of underlying to the various pressures and promises that the "Latin kings" would protect them from the Albanian zulum ${ }^{5}$ (Peruničić 1989: 64).

The Congress of Berlin was followed by a period marked by the most severe persecutions, physical destruction and displacement, as well as anarchy which consequences had a negative impact on the Serbian population. After 1878, a large number of Serbians left Old Serbia as a result of these events. The number of emigrants from 1876 to 1912 was not easy to determine and the data ranged from a few tens of thousands to several hundred thousand. After the migration, numerous Serbians'properties began to be settled after 1878 by the Catholic Albanians - fandas, whose actions significantly influenced the increase of anarchy and caused even greater fear among the Serbs. The contemporary of many events in Old Serbia, Professor of Prizren Bogoslovija, Petar Kostić, left valuable information from those parts and believed that the period of the Serbo-Turkish wars (1876-1878) was pernicious to the Serbian population. He alleged that the

4 Archive of Serbia (=AS), the Ministry of Foreign Affairs (=MFA) Political Department (=PD), 1889, roll 101, folder III, file VI, no number, the Warden of Prizren Bogoslovija Petar Kostć - to the Minister of Foreign Affairs, Prizren, January 31, 1889.

5 Zulum is a Turkish word for persecution. 
Serbs were leaving their land at that time, which was later populated by Albanians from Serbia. On the deserted land, instead of the Serbian peasants, aghas inhabited the Roman Catholic Albanians - fandas - whose number was negligible until 1878. Their settlement significantly impeded the survival of the already thinned-out Serbian population and led to increased anarchy (Mikić 1988: 27). The claim of Petar Kostić also coincides with the opinion of other researchers from recent times (Vickers 1988: 50).

The Russian Consul in Prizren Ivan Stepanovich Yastrebov notes that during his service there were 1,910 Catholic houses and states that there were 5,000 in the Dečani District, 3,000 in Peć, and 1,900 Catholics in Prizren (Jastrebov 2018: 47).

Branislav Nušić, who was the Consul in Prishtina from 1893 to 1896, in 1894 made a report on a trip from Prishtina to Skadar, reviewing the penetration of Roman Catholic propaganda among the Albanian people. He described the fandas, members of the Roman Catholic faith, as the wildest of tribes, among which was the blood revenge was expressed, on which the friars did not react. According to Nušić, this behavior of the friars was intended to use the fandas only to strengthen their influence and to put them in the service of their interests (Jagodić 2010: 274). The friars spread their propaganda from Prizren, which since 1821, when the bishop of Janjevo moved, became the seat of the Roman Catholic Diocese (Nušić writes metropolis). Roman Catholics gathered around the bishop in Prizren spoke to each other in Serbian, until the 1870s, Roman Catholic Albanians who came from Djakovica, Peć and Skadar district began to suppress them. ${ }^{6}$ After the Serbo-Turkish war, there were approximately 200 Roman Catholic homes in Prizren. They were mainly against the Serbs and on the Turkish side, and they resolved mutual disputes in spite of authorities and through their religious leaders (Nušić 2005: 50-51).

Prizren, as one of the centers in the Kosovo Vilayet, captured the special attention of the Austria-Hungary. Thanks to their skills and money, they bribed almost all the prominent Albanian leaders in that city. Compared to them, the Roman Catholic Church conducted its propaganda with great success. That is why the Austro-Hungarian consulate in Prizren became completely independent from that of Skopje (Toleva 2018: 104). At the end of the 19th century, Vatican intended a larger sum of money to the Roman Catholic Diocese

6 The Consul Sima Avramović says in one report that there is an area in Skadar district, southeast of Skadar, that is populated by Catholic Albanians - fandas. He noted that they had certain privileges, which included carrying weapons and that they had acquired this right by fighting with the Mohammedans against Montenegro, at the urging of their friars. That area also had an elder who was called "Captain Pasha." Archive of Serbia (=AS), the Ministry of Foreign Affairs (=MFA) Political and Educational Department (=PED), 1901, raw (IV), Confidential № 326, Consul S. Avramović - to M. Vujić, the Minister of Foreign Affairs, Prishtina, October 25, 1901. 
in Prizren. Thanks to this, the fund with three elected citizens, Roman Catholics was formed. Loans were given from that fund at a low interest rate of $8 \%$ to Roman Catholic merchants and widows. It was the loans from the established fund that contributed to the declension of Serbian traders who were much more skilled and successful in trade than their Roman Catholic colleagues. Roman Catholic merchants presented competition not only to Serbian but also to Turkish merchants, who often traded high-profit items and forbade their wives to shop at Serbian stores. This form of trade had a negative effect on Serbs, who were mostly failing and forced to move out. In addition to establishment of the fund, the Roman Catholic Diocese also bought chifliks ${ }^{7}$ and land in the vicinity of Prizren and on them settled fandas from the interior of the Kosovo Vilayet. Doing this, it increased the Roman Catholic population (Peruničić 1989: 175).

It was because of such Roman Catholic propaganda among the Albanian people that the number of fandas increased, so that in the mid-first decade of the 20th century, there were 260 homes with a population of 1,560 in Prishtina, Prizren and Peć sanjak. This is illustrated by statistics at the request of the Government of Belgrade compiled by the Consul of the Kingdom of Serbia in Prishtina, Miroslav Spalajković in $1905 .^{8}$

\begin{tabular}{|c|c|c|c|}
\hline 1. & Serbs, Orthodox religion & 12.415 homes & 248.300 inhabitants \\
\hline 2. & Arnavuted Serbs Mohammedans ${ }^{9}$ & 15.600 homes & 390.010 inhabitants \\
\hline 3. & Serbs, Catholics & 108 homes & 1.750 inhabitants \\
\hline 4. & Serbs, Mohammedans from Bosnia & 50 homes & 1.200 inhabitants \\
\hline 5. & Serbs Protestants & & 1 inhabitant \\
\hline 6. & Arnavuts, Catholics & 260 homes & 1.560 inhabitants \\
\hline 7. & Albanians & 1.000 homes & 20.000 inhabitants \\
\hline 8. & Turks & 270 homes & 3.230 inhabitants \\
\hline 9. & Jewish people & 50 homes & 300 inhabitants \\
\hline \multicolumn{2}{|c|}{ Total: } & 29.753 homes & 666.351 inhabitant \\
\hline
\end{tabular}

In addition to the statistics he produced, the Consul Spalajković noted that the number of Serbian houses in Peć municipality ${ }^{10}$ was 1.000 and that Serbs were more numerous than Catholic Albanians who had 240 homes. He also cited the main villages inhabited by fandas, including: Djurakovac, Leskovac, Renovac, Zlokućane, Potočani, Kruševo, Radulovce, Klina, Vidanje, Paskalica, other

$7 \quad$ Chiflik is a Turkish term for property in Ottoman Empire that belonged to aghas and beys, inhabited by dependent peasants who cultivated it.

8 AS, MFA PED, 1905, raw 20, PP No. 485, the Consul M. Spalajković - to N. Pašić, the Minister of Foreign Affairs, Prishtina, 9, May 1905; Documents on Foreign Politics of the Kingdom of Serbia 1903-1914 (=DFPKS), book 1, notebook 3/II, 767-768, doc. 303.

9 Arnavuted Serbs areSerbs who converted in Islam and became Albanians.

10 Kaza is a Turkish term for municipality. 
Kruševo $^{11}$, Stup, Budisavce, Donji Stup, Lug, Jagoda, Novoselo-Dencko, Poljce, other Novoselo, Prlina, Suva Klina, Grabanica, Duge Njive ${ }^{12}$, Trstenik, Berkovo, Grebnik, Dolac, Štupalj, Dolovo and Pogradje. In these villages there were 10 to 15 Catholic houses, and in Djurakovac, Vidanje, Budisavci, Berkovo, Dolac and Podgradje there were 2 to 3 Serbian houses each. Leskovac and Zlokućane were marked as the largest Roman Catholic villages. The names of these villages indicate that they were once purely Serbian, but the violence and persecution committed against the Serbs influenced their migration. ${ }^{13}$

The number of Roman Catholic Albanians has increased over the time, thanks to Austria-Hungary, which saw them as a mean of spreading influence in the territory of Old Serbia. The Roman Catholic clergy served for that purpose from northern Albania (Hrabak 2005: 243-262). It acquired the right to do so by a treaty on the Protectorate signed between the Emperor Matthias and Sultan Ahmet I, in Vienna on July 15, 1615 (Draškić 2000: 84). Considering the fact that the Roman Catholic Albanians were in the minority relative to the Mohammedan and Serb population, the Dual Monarchy sought to win over some of the more prominent Albanians in order to achieve their goals as enshrined in the Drang nach Osten principle. According to the data of the Austro-Hungarian government, the composition of the population in Prishtina, Prizren and Peć sanjak in 1903 was as follows: ${ }^{14}$

\begin{tabular}{|l|r|r|r|r|r|r|}
\hline \multirow{3}{*}{ Sanjak } & \multicolumn{7}{|c|}{ Population Number } \\
\cline { 2 - 7 } & \multicolumn{2}{|c|}{ Albanians } & \multicolumn{4}{c|}{ Slavs } \\
\cline { 2 - 7 } & Muslims & Catholics & $\begin{array}{c}\text { Exarchates } \\
\text { (Bulgarians) }\end{array}$ & Patriarchists & Muslims & $\begin{array}{c}\text { Catholics } \\
\text { (Serbs- } \\
\text { Croats) }\end{array}$ \\
\hline Prizren & 126.420 & 1.340 & 17.232 & 22.500 & 1.932 & \\
\hline Prishtina & 145.508 & 565 & & 87.701 & 17.264 & 3.011 \\
\hline Peć & 130.690 & 11.695 & & 16.460 & 2.000 & \\
\hline Total & 402.618 & 13.600 & 17.232 & 126.661 & 21.196 & 3.011 \\
\hline
\end{tabular}

11 Today, there are Veliko and Malo Kruševo.

12 In document it is noted as Dugoljevo.

13 DFPKS, book I, notebook 4/II, 680, doc. 256.

14 The information encountered in this table, which we abbreviated for the purposes of work, requires comment. Namely, the Prizren sanjak mentions 17,232 exarchates (Bulgarians), however, it should be noted that within this sanjak there were Tetovo and Ljuma municipalities, and that number is encountered precisely in the Tetovo municipality. The presence of Roman Catholics, in brackets stands Serb-Croats, in the Prishtina sanjak is related to the existence of the Roman Catholics who spoke Serbian and lived in Janjevo and the villages of Letnička župa. It can be seen that the largest number of Roman Catholics - fandas was in Peć sanjak: there were 8,595 in the Djakovica municipality, and 3,100 in the Peć municipality (Toleva 2018: 546-548). Until recent times, the largest number of Roman Catholics remained in Djakovica. 
Official representatives of Austria-Hungary in Old Serbia were implementing their country's policies. Their sentiment towards the Serbian population is also evidenced by the information recorded by Todor P. Stanković on his accession as Consul of the Kingdom of Serbia in Prishtina in 1892. He stressed that his first and foremost task was to suppress or mitigate the negative attitude of the AustroHungarian consul in Skopje, Schmuker. Only after that, before him was the task of assuring Wali of friendship and common interests of Serbia and Turkey. ${ }^{15}$

Austro-Hungarian actions have not gone unnoticed by the representatives of Turkish authorities. Prishtina district chief noted that the Albanians actions directed against the Serbian population were supported by the Austro-Hungarian side. Kosovo Wali Hafiz Pasha attributed all the unrest in Metohija to the work of the Austro-Hungarian secret services. He believed that the sole purpose of these disorders was to provoke major disturbance that would serve as an excuse for Austria-Hungary to occupy Kosovo's Vilayet. The fact that the AustroHungarian propaganda was really doubted, the knowledge that Sultan, on the warning of the Russian ambassador on Porte that it was done by plan and that only Christians were suffering, much less Roman Catholics, "did not deny that one foreign force has a finger in it, which, through its agents, is doing that"also leads us (Ćorović 1992: 22).

The actions of Austro-Hungarian agents in the terrain became more intense and aimed to strengthen the influence of their propaganda. They had a large share and significantly influenced the situation in Prizren, marked by disorders and constant intrigues against Metropolitan Dionysius. The resulting situation also represented the work of Austro-Hungarian propaganda for the Consul of the Kingdom of Serbia in Prishtina, Sveta Simić as well. He believed that some Serbs embroiled unconsciously in these intrigues, did not know what they were serving for and who would benefit from them. As an illustration of this claim, the Consul Simić cited the behavior of Dimitrije Mitić, the teacher of Prizren Bogoslovija, whom he calls "the traitor to Serbian origin, Serbian ideas and Serbian thought." He supported his claim by the fact that Mitić, first with Cvetko Blagojević, owner of a tavern and later with Mladen Antić, a shoemaker, said the following words: "that we can never expect anything from Serbia, because the state is weak and powerless; as such, it must then collapse and Austria occupy us, etc.". He suggested unition and joining toAustria and claimed that Austria was making progress, that it would provide them with material assistance and weapons, unite with the fandas, resist Turkish violence. ${ }^{16}$ This view of Mitić raised the suspicion of the Minister of Foreign Affairs and Metropolitan of

15 AS, MFA PED, 1895, raw 426, no number, the Consul T. P. Stanković - to S. Novaković, the Minister of Foreign Affairs, Niš, August 20, 1895.

16 AS, MFA PED, 1899, raw 175 (VII), PP № 483, the Consul S. Simić - to V. Djordjević, the Minister of Foreign Affairs, Prishtina, October 18, 1899. 
the Diocese of Raška and Prizren, and it was decided that he should be removed from Prizren Bogoslovija. That is why Mitić visited the Consulate in Prishtina, acknowledged the words spoken, but not that someone persuaded him and paid to seek supporters for such ideas. ${ }^{17}$ The case of teacher Mitić in Prizren has revealed to us the intrigues that Austro-Hungarian agents used to prepare the terrain for their aspirations.

Such and similar cases, in which some Serbs were involved, were present throughout Kosovo Vilayet. Austro-Hungarian propaganda sought to gain supporters for its goals in the Novi Pazar and Pljevlja sanjak and in Prizren. Their agents managed to attract individuals in Pljevlja, Prijepolje and Bijelo Polje in different ways, and they directed their work to Sjenica. Supporters of AustroHungarian agents in those regions publicly opposed the work of the Metropolitan and continued to work against him, but without great success. Unlike them, on the side of the Serbian patriots were the Bajić and Živković family in Pljevlja, Borisavljević family in Nova Varoš, Veseličić family in Prijepolje, Prota Vasilije Cemović in Sjenica and the Murakovac family in Bijelo Polje, who saw the Metropolitan as an extraordinary Serb and friend. One of the aims of Austro-Hungarian propaganda was to create a division between the people and the Metropolitan. ${ }^{18}$ It seems that the Metropolitan's reputation among the Serbian population was an obstacle to the achievement of Austro-Hungarian goals, so stories of the planned murder began to circulate. Confirmation of this can be found in the letter from prota Srećko Ostojić to the Metropolitan, who, in the conversation with the Mitrovica military kaymakam ${ }^{19}$ Sali Bey, made known that Austria-Hungary was planning to kill the Metropolitan. The intense work of the Austro-Hungarians is confirmed by the story of the brother of the famous Beshur bey Mahmudbegovic, from the most reputable and wealthy Peć family, who, when meeting with the Metropolitan, claimed that a large amount of money had been separated and distributed for that purpose to the Albanians in the Peć sanjak. The Austrian agents, working in accordance with the foreign policy of their country, relied mainly on the fandas from the Peć and Prizren sanjak. In order to achieve their goals, they did not choose the means, they stirred up discord among the Serbian people, provoked dissatisfaction, portrayed the work of the Metropolitan in a negative light, sought people who would accept conversion, working together with fandas and relying on Austria-Hungary, and did not exclude the killing of individuals who would found themselves as an obstacle along the way. ${ }^{20}$

17 AS, MFA PED, 1899, raw 175 (VII), PP № 495, the Consul S. Simić - to V. Djordjević, the Minister of Foreign Affairs, Prishtina, October 22, 1899.

18 AS, MFA PED, 1899, raw 175 (VII), PP № 483, the Consul S. Simić - to V. Djordjević, the Minister of Foreign Affairs, Prishtina, December 8, 1899.

19 Kaymakam is a Turkish term for municipality (kaza) governer, prefect.

20 Documents on Raška Region 1890-1899, 607-609, doc. 514. 
The Propaganda of the Dual Monarchy considered that it could find its stronghold in Janjevo, where Roman Catholics of Slavic origin (Serbs, Ragusans) lived. It was for this reason that a new teacher was sent to that place, whose actions were significantly different from his predecessor. He sought to stick in the minds of residents of Janjevo an awareness of Croatian ancestry. He tried to force the church to sing songs in "Croatian language", but he encountered resistance from the clergy. Even the population did not agree with this idea, so the attempt of the Austria-Hungary to achieve their intentions, despite the intervention of the Consul from Skopje, failed completely. ${ }^{21}$

The Austro-Hungarian propaganda and its work also influenced the engagement of official representatives of the Kingdom of Serbia in the Ottoman Empire. The Consul in Prishtina, Sveta Simić, after visiting the area under his jurisdiction, realized the situation on the terrain and was assured of the right condition. He tried to strengthen ties between the people and the Metropoli$\tan$ Dionysius and concluded that there were no disagreements in the northern parts of the diocese, except in Prizren and Peć. He believed that this was the result of numerous intrigues by some Serbian payers from Skopje. Wanting to prevent the work of Austro-Hungarian agents in some way, the Consul Simić tried to contact the more prominent Albanians from the Peć municipality. Although he did not manage to make contact with their leaders, he did succeed with a few lower ranks that had an impact on the events. Among them were: Sejdi Saka, Tahir Fazlija, Bib Doda i Pran Paljoka. He also sought to establish links with Ram Ljutan, the leader of Albanians in Drenica, as well as with several other smaller tribe leaders. He also hired a commissioner with the task of checking the opinion of Albanians in the Peć municipality, among whom ideas had to be spread, that would adversely affect the work of the Austro-Hungarian propaganda. $^{22}$

The situation in Peć and its surroundings became a concern, which was also contributed by the largest concentration of the fandas. By the beginning of the twentieth century, the leading role among the Albanian people had Mula Zeka, but he had been old and ill. The activity of Zeynel Bey Mahmutbegović, who came under the influence of Austria-Hungary, became increasingly prominent. His commitment was also influenced by the Roman Catholic priests who frequently visited him. Probably they also influenced the idea of sending a petition to the Turkish authorities with a large number of signatures for the appointment of Zeynel Bey as a mutesarif ${ }^{23}{ }^{24}$

21 Documents on Raška Region 1890-1899, 586-587, doc. 491.

22 Documents on Raška Region 1890-1899, 609-610, doc. 514.

23 Mutesarif is a Turkish term for governor of sanjak.

24 AS, MFA PED, 1900, raw 22 (I), Confidential № 20, the Consul S. Simić - to V. Djordjević, the Minister of Foreign Affairs, Prishtina, February 9, 1900. 
In the Peć municipality, Albanian mutual relations were disturbed, complete anarchy prevailed and its consequences were felt at every step. The Consul Sveta Simić notes that there was no tribe, village or even a tribe that was not in conflict with each other. The consequences of these conflicts were visible and often resulted in killings. It was reported that there were five casualties in only one conflict in the immediate vicinity of Dečani. All disagreements and conflicts arose from the desire to seize Serbian properties. Numerous Serbs, who were forced to flee their estates due to the persecution, leaving their neighbors more space for new conflicts. Stronger neighbor emerged victorious in the fight for Serbian properties. The situation was also aggravated by the work of AustroHungarian agents, who gained upon all the major people and fugitives in the Peć municipality. It was openly said that they would welcome Austria-Hungary with song, and they would fight Serbia until the last bullet. The friars engaged and said that the Austria-Hungary obeyed the laws and customs of the Albanians, unlike Serbia, and cited the situation of the Mohammedans in Bosnia as an example. One of the kavaz ${ }^{25}$ from Sarajevo, who visited Peć and the Peć municipality, served as support for this work and ideas. When he visited these areas and met with Austro-Hungarian supporters, he shared money and instructions. Austro-Hungarian diplomats were also engaged in this task, seeking Roman Catholics to obtain a ferman for the building of a church in Peć and a help of 1,000 lire for this purpose. ${ }^{26}$

The anarchy that engulfed the Peć municipality did not go in favor to all Albanians. Among them, in the most ordinary conversation, various ideas and opinions could be heard that the Turkish authorities were not able to make the order. The Roman Catholic Albanians were divided in their believes: a smaller part declared that they wanted these lands to belong to Italy, while the majority favored Austria-Hungary, whose agents worked more vigorously and systematically and to whom this circumstances went in favor. One thing was for sure, all the Albanians, both Mohammedans and Roman Catholics, were despising Serbia and perceiving it as their greatest enemy. ${ }^{27}$

That the Roman Catholic propaganda in the Peć municipality followed closely the events is evidenced by the procedure of the head of its mission in Peć Don Lorenzo, who tried to prevent the conversion of some Roman Catholic Albanians to Islam. This also happened when some Milovan Sadik and Ismail Liman, the fandas from the village of Pogradje converted to Islam. To scare

25 Kavaz is a Turkish term for armed escort, honorary guard of foreign diplomatic representatives in Turkey.

26 AS, MFA PED, 1900, raw 22 (I), Confidential № 30, the Consul S. Simić - to V. Djordjević, the Minister of Foreign Affairs, Prishtina, February 16, 1900.

27 AS, MFA PED, 1900, raw 22 (I), Confidential № 67, the Consul S. Simić - to V. Djordjević, the Minister of Foreign Affairs, Prishtina, March 31, 1900. 
the other fandas who intended to go the same route as the two men abovementioned, Don Lorenzo blackmailed their heads with 50 Turkish liras each. ${ }^{28}$

As the twentieth century passed by and as anarchy overtook the entire Kosovo Vilayet, so did dissatisfaction among all the Albanians. The disorders affected Peć, Prizren and Djakovica. At the beginning of 1902, there was a skirmish in Djakovica among Albanian Mohammedans, sparked by the conflict between Roman Catholics and Mohammedans. It was not the first conflict between the two sides. This is evidenced by the pledge of honor that the Albanian Mohammedans concluded, that no Muslim should kill another Muslim, at the expense of a Christian, whether Roman Catholic or Orthodox. This is exactly the case in Djakovica, where Mohammedan Sait Mulja owed the blood to the fanda Nikola Drec. Nikola hired well-known Djakovica leader and wealthy military liferant Murtez Pasha for revenge, to whose suasion Azir Sulja killed Sait Mulja. The killing caused unrest among the Mohammedans and the wider region, as did Albanians'determination from Malesija to set the house of Murtez Pasha in fire. The conflict took on a serious scale and led to the intervention of the army and gendarmerie under the command of Šemsi Pasha and Bajram Curi. However, Murtez Pasha was determined to defend himself until the last drop of his blood, gathered around 200 of his men and locked himself in a tower. Albanians' fierce reaction, which also engulfed Malesia, was triggered by the knowledge that the pledge of honor had not been respected and that the injured party could not claim blood because it was a paid murder. If, on any occasion, the killing was caused by personal revenge, the injured party could receive compensation in blood or money, which Murtez Pasha would very gladly and easily pay for. ${ }^{29}$

The conflicts between the Albanians in Djakovica did not cease and demanded the reaction of the Turkish authorities. Zafir Nikolić, as a commissioner, reported to the mayor of the Toplica district on this situation. He reported that there had been rebellion in Djakovica led by Bajram Curi and Alaybey. The situation was similar in Prizren, where Hamdi Pasha was. His engagement did not lead to the desired results and to reconciliation among the Albanians. It was assumed that Austria-Hungary was behind the disorders. Prizren Turks reported that Šerif Effendi, son of Šaban Effendi, had received 2,000 ducats from AustroHungary to incite Albanians to disorder. After that, stories began circulating in Prizren that Austria-Hungary would occupy Old Serbia. ${ }^{30}$

28 AS, MFA PED, 1902, raw 213 (I), PP№ 334, the Consul S. Avramović - to M. Vujić, the Ministerof Foreign Affairs, Prishtina, March 31, 1902.

29 AS, MFA PED, 1902, raw 26 (II), Confidential № 10, the Consul S. Avramović - to M. Vujić, the Minister of Foreign Affairs, Prishtina, January 22, 1902.

30 AS, MFA PED, 1902, raw 26 (IX), Confidential number, The Chief of the Toplica district - to M. Vujić, the Minister of Foreign Affairs, Prokuplje, April 19, 1902. 
Peace on the terrain could not be established not only because of Albanians' mutual conflicts, but also because of the atrocities committed by the fandas against the Serbs. One of the major conflicts between the fandas and the Serbs took place in March 1902 in the village of Drsnik, in the Peć municipality. There were 24 Serbian houses in that village, 4 of which belonged to the strongest Ribać family with 150 members. Miladin Ribać had conflict with Kolj Maraš over some shrubs and thorns that the Ribać family were collecting for themselves. There was a shooting that killed Kolj Maraš and Kosta, Miladin's brother. Other fandas became involved in the conflict, two were killed, one was injured and Vuča Ribać was also wounded. When news of the casualties spread, 200 fandas gathered to kill all the Ribać family and burn their homes. In this intention, they were prevented by the famous villain Tahir Fazli, zaptija ${ }^{31}$. The fandas burned the barns, robbed some things and about 500 heads of cattle and sheep, but Tahir returned the cattle back. The Ribać family kept all the Martini-Henry rifles $^{32}$ and one revolver from the killed one. Tahir Fazlija's behavior should not be surprising, since Miladin Ribać had bribed him many times before, believing that only in this way can he provide himself and his family some form of protection. However, after this conflict, guard Tahir was no longer satisfied with the money, but demanded an act of Chaush ${ }^{33} \cdot{ }^{34}$

Knowing that in this way the confrontation with the fandas was not over and that they were waiting for the right moment to seek revenge for the dead, Miladin decided to seek help from Belyaev, the Russian Consul in Prizren. ${ }^{35}$ The Consul immediately and officially addressed the Peć perfect in a letter and asked for protection. However, instead of taking some action, the Mutesariff assigned the task to Khalil Pasha from Peć. Insincere in that intention, Khalil Pasha not only took no measures to protect the Ribać family, but also discouraged certain Albanians who wanted to mediate between the conflicting parties. Khalil Pasha had no interest in settling the quarrels, for he imagined that the Ribać family would move out and he would grab their property. In the meantime, the fandas started to get revenge, and at night, they lit one tower, six stables and eleven barns. To the Ribać family, who did not leave their homes in fear, only the most necessary buildings remained. At that moment, they were abandoned by the authorities, Khalil Pasha, and some of the Albanians who could find themselves as mediators and left to their own destiny. The only

31 Zaptija is a Turkish term for guard, gendarme.

32 The Martini-Henry is a breech-loading single-shot lever-actuated rifle that was used by the British Army.

33 Chaush is a Turkish term for non-comissioned officer in the Turkish army.

34 AS, MFA PED, 1902, raw 213, PP№ 334, the Consul S. Avramović - to M. Vujić, the Minister of Foreign Affairs, Prishtina, March 31, 1902.

35 AS, MFA PED, 1902, raw 26 (VIII), Confidential № 64, the Consul S. Avramović - to M. Vujić, the Minister of Foreign Affairs, Prishtina, April 5, 1902. 
option was to seek help again from the Russian Consul Belyaev, who could directly contact Khalil Pasha or his son-in-law Zeynel Bey. ${ }^{36}$

Wanting to help the Ribać family, Belyaev sent a letter to Zeynel Bey, but there was no help. The endangered family was forced to pay 9,000 groschen for the rifles they kept for themselves after the conflict. All they got was the pledge of honor that they could go out from the house for fifteen days. ${ }^{37}$ The free movement for one man from each house and the security and property guarantee they received thanks to Tahir Fazlia did not help the Ribać family much, as the fandas burned all their hay and barns again at night, damaging another 100 lire. The consul of the Kingdom of Serbia in Prishtina Sima Avramović was involved in the resolution of this case. He saw the cooperation between the fandas and the Turkish authorities and thought that Khalil Pasha from Peć was behind it. The fandas were chifliks ${ }^{38}$ of Khalil Pasha, who intended to move out the Ribać family and seize their estate valued at about 3,000 lire. The consul believed that the eviction of this family would have a negative impact on other Serbians from Drsnik, Kijevo and other villages of the Peć municipality. That is why he suggested to the Belgrade Government to influence Khalil Pasha through Constantinople, which, according to him, could calm the situation and work out that the Ribać family did not pay blood because they had been badly harmed by the fandas. ${ }^{39}$

The Ministry of Foreign Affairs of the Kingdom of Serbia in Belgrade, based on a report in Prishtina, had information that Austro-Hungarian secretly worked against the Serbs. The action took place through the Albanians, Muslims and Catholics in Djakovica and through the friars in Peć. For this purpose, 7,000 napoleons were allocated in Djakovica alone. In addition to money, sending weapons through Prizren and Skadar was organized as well. ${ }^{40}$ Based on this knowledge, representatives of the Kingdom of Serbia who served in the Ottoman Empire were instructed by Belgrade to closely monitor the work of Austria-Hungary in Old Serbia and to prevent further action through their Russian colleagues. And they believed that Austria-Hungary, through the friars, was working on delivering weapons that ended up in the hands of the Albanian people. Austria-Hungary also skillfully took advantage of the situation in which Russia found itself in the Far East, so despatches were sent from Pljevlja on the defeat of the Russian fleet. Such and similar movies coming from the Austro-Hungarian side significantly

36 AS, MFA PED, 1902, raw 26 (X), Confidential № 85, the Consul S. Avramović - to M. Vujić, the Minister of Foreign Affairs, Prishtina, May 21, 1902.

37 AS, MFA PED, 1902, raw 213 (X), Confidential № 95, the Consul S. Avramović - to M. Vujić, the Minister of Foreign Affairs, Prishtina, June 11, 1902.

38 Chifliks are depended peasants on the property of Khalil Pasha.

39 AS, MFA PED, 1902, raw 26 (XII), Confidential № 117, the Consul S. Avramović - to M. Vujić, the Minister of Foreign Affairs, Prishtina, June 29, 1902.

40 DFPKS, book 1, notebook 3/II, 825, doc. 326. 
influenced the agreement between the Muslim Albanians and the Roman Catholics, which envisaged the killing of Serbs in Prishtina sanjak. ${ }^{41}$

During summer of 1905, complete anarchy prevailed in the Peć municipality, which resulted in the visible thinning of the Serbian people. Such was the picture throughout Old Serbia, and for two years, from 1904 to 1906, the persecutions against the Serbian population were diverse (Batakovič 2014: 90). As a result of this situation, many villages were abandoned, and in those places where the Serbs survived, they were imperceptible, because they did not leave their homes because of fear. The Kosovo Wali and Khilmi Pasha were aware of the situation through information coming from the Serbian side. However, they remained mute and took no steps to prevent anarchy and make order. The resulting situation also disadvantaged the Metropolitan of Raška and Prizren, who was thinking of closing down the churches and saying that he himself "proclaimed the persecution and extermination of Orthodox Serbs by opponents of religion - Mohammedan and Catholic". 42

The atrocities against the Serb population in the Kosovo Vilayet were multiplied on a daily basis and the Government in Belgrade was regularly informed about them through reports sent by its Consul from Prishtina. These reports listed the victims by name, the damage caused to them, as well as the names of the perpetrators, among whom were those from the Peć municipality. The movement of the Albanian Mohammedans in the Peć municipality developed, and was joined by Roman Catholics Albanians under the leadership of Zef Djonović and Abdul Kopitić of Zlokućane. They stayed in Peć forests in troops and received salaries from the Austrian consulate in Mitrovica for their deeds, while the others, in agreement, distributed the loot gained by the robbery. ${ }^{43}$

The numerous atrocities committed against the Serbian population in the Peć municipality by the Roman Catholic Albanians - fandas did not lag behind the crimes committed by the Albanian Mohammedans. A large number of atrocities had been committed following instructions received from agents of Austrian political propaganda. This is evidenced by the fact that the AustroHungarian representative in Constantinople, at the request of his Russian colleague, influenced, through the friars, the prevention of the fandas persecution, at a time when there were enough Turkish troops in the Peć and Prizren sanjak. It turned out that the Austro-Hungarian Consul did not take care of the Serbs, but of the fandas, who, due to their misdeeds, could have been hit by the Turkish army. However, when the number of soldiers decreased, the Austro-Hungarian

41 AS, MFA PED, 1905, raw 289, PP. № 392, Member of the Parliament D. S. Čohadžić - to J. M. Žujović, the Minister of Foreign Affairs, Constantinople, May 23, 1905; DFPKS, book 1, notebook 3/II, 845-846, doc.335.

42 DFPKS, book 1, notebook 3/II, 919-920, doc. 379.

43 DFPKS, book 1, notebook 3/II, 921-923, doc. 379. 
Consul neither engage in the matter, nor he respond to calls from his Russian colleague, but openly stood in defense of the fandas. He spoke out for his actions by the fact that his involvement would disrupt the relation with Roman Catholics, and especially in the situation if the greatest cutthroats would be caught because of committed crimes. ${ }^{44}$

The main initiator of the Roman Catholic propaganda for the Peć and Prizren regions was the Bishop of Prizren, while the Roman Catholic Albanians center was located in Zlokućane. The bishop followed a number of Albanian gatherings and was trying to meet Zeynel Mahmutbegović, the Albanians leader from Peć. In all these events, Austria-Hungary saw the achievement of its goal, which meant that the Serbian population in Metohija would be completely destroyed and that Kosovo would be as thin as possible. The disappearance of the Serbs in the Peć and Prizren sanjak would affect the creation of free space from Mitrovica to Kačanik, thus opening the way for further penetration of Austria-Hungary to the south. At the same time, the influence and possibility of the Kingdom of Serbia's activities in Old Serbia would be suppressed. It would be suppressed in this way, and its further work on spreading propaganda and national consciousness would be hindered. For this reason, Austria-Hungary found allies in the Albanians and the Sultan's policy of indulgence, as well as among the Bulgarians. ${ }^{45}$

The persistence of the Roman Catholic Albanians who worked for AustroHungarian interests is reflected in the fact that they targeted respectable Serbian hosts. One of them was Todor Bošković Lazarević from the village of Drenovčić, in the Peć municipality, who during 1905 every night heroically resisted the attacks of the fandas. Hidden in a stone tower, Todor was able to resist, with the help of a weapon obtained from Prishtina Consul Miroslav Spalajković. Considering the danger that Todor was threatening, the consul gave him twenty rifles Martini first and then two more high-speed rifles. Thanks to the weapons obtained, Todor was able to resist the fandas that attacked in the troops of 500 men each. ${ }^{46}$ The attackers were from the village of Zlokućane, the center of Roman Catholic propaganda, often visited by the bishop of Prizren. The Turkish army went to Zlokućane with the intention of looking for the perpetrators of these events among the fandas, but at the insistence of the friars and the Austro-Hungarian Consul from Prizren it was therefore removed. Among the most influential who enjoyed the support and protection of the Roman Catholic priests in this area were: son of Huak and Bafter Naja from Bobić village, Ljuš Rap, Jusuf Sadik and Rama Sadik from Stup, Sokol

44 AS, MFA PED, 1905, raw 217, PP. № 671, the Consul M. Spalajković - to J. M. Žujović, Representative of the Minister of Foreign Affairs, Prishtina, June 27, 1905; DFPKS, book 1, notebook 3/II, 966-970, doc. 401. Ibid.

46 DFPKS, book 1, notebook 4/II, 684, doc. 257. 
Bekim of Naglavak, Prem Ria from Budisavac, some Peter from Luka village, Kolj Ajdar, formerly a guard, and Nua Nuke Pać from Lug. ${ }^{47}$

The difficult position of the Serbian population of the Peć region required greater involvement of Serbian and Russian diplomats. Representatives of the Kingdom of Serbia considered the possibility of opening consulates in Peć. They felt that in this way the Serbs could be given the necessary protection and assistance. In addition, they thought they might benefit from the presence and residence of Metropolitan Nićifor, and they were convinced that he could suppress foreign propaganda and possible conversions of some prominent Serbian families, such as the Ribać family from Drsnik. The Prishtina Consul Miroslav Spalajković also expressed such an opinion, emphasizing the importance ${ }^{48}$ and visit of the Roman Catholic bishop from Prizren to Zlokućane, whose aim was to persuade the villagers to tie the pledge of honor against the Serbs.

The Russian Consul in Mitrovica, Arkady Alexandrovich Orlov, in conversation with Miroslav Spalajković, emphasized that he had timely informed his embassy in Constantinople about the suffering of the Serb population, but did not have any specific instructions that could prevent such occurrences. In addition, he did not find the understanding and interest of the Austro-Hungarian Consulates and their Consuls, which he claimed that when mentioning the state of Serbian population was like "swallowing poison". ${ }^{4}$

These and other examples of the behavior of the Austro-Hungarian diplomats and the Roman Catholic priests clearly indicate the cooperation with the fandas and the common goal that meant destroying the Serbian population not only in Prizren and Peć sanjak but throughout the whole Old Serbia.

\section{UNPUBLISHED SOURCES}

Archive of Serbia, Ministry of Foreign Affairs, Political Department.

Archive of Serbia, Ministry of Foreign Affairs, Political and Educational Department.

\section{PUBLISHED SOURCES}

Jastrebov 2018: Ivan Stepanovič Jastrebov. Old Serbia and Albania. Belgrade: Official Gazette. Nušić 2005: Branislav Dj. Nušić. From Kosovo to Blue Sea: Notes From Travel through Albanians 1894. Belgrade: Čigoja.

Pejković 2014: Ljiljana Aleksić Pejković. Documents on Foreign Policy of the Kingdom of Serbia, book. 1, notebook 3/II. Belgrade. Serbian Academy of Sciences and Arts.

47 DFPKS, book 1, notebook 4/II, 720, doc. 277.

48 DFPKS, book 1, notebook 3/II, 963-965, doc. 400.

49 AS, MFA PED, 1905, raw 217, PP. № 626, the Consul M. Spalajković - to J. M. Žujović, Representative of the Minister of Foreign Affairs of Prishtina, June 10, 1905; DFPKS, book 1, notebook 3/II, 914, doc. 374. 
Pejković 2014: Ljiljana Aleksić Pejković. Documents on Foreign Policy of the Kingdom of Serbia, book.1, notebook 4/II. Belgrade. Serbian Academy of Sciences and Arts.

Peruničić 1989: Branko Peruničić. Persecution of Aghas and Beys in the Kosovo Vilayet 18781913. Belgrade: Nova knjiga.

Petrović 1997: Milić F. Petrović. Documents on Raška Region 1890-1899. Belgrade: Historical Museum of Serbia.

\section{REFERENCES}

Batakovič 2014: Dušan. T. Batakovič. Косово и Метохия - история и ugeoлoıия. Ekaterinbur: ИзАательство Уральского университета.

Bataković 1984: Dushan T. Bataković. „Attempt to Open a Serbian Consulate in Prizren 18981900“. Historical Review, no. 31. Belgrade: Historical Institute, 249-259.

Draškić 2000: Sreten Draškić. Europe and Albanian Question (1830-1921). Contributions to the Study of the History of Albania from the Beginning of the National Revival (1830) to the Confederation of Ambassadors in Paris (1921). Belgrade: Serbian Literary Guild.

Jagodić 2010: Miloš Jagodić. „Report of Branislav Nušić on Traveling from Prishtina to Skadar 1894“. Mixed materials. Book XXXI, Belgrade: Historical Institute, 259-287.

Kosovo and Metohija in Serbian History, Belgrade 1989: Serbian Literary Guild.

Mikić 1988: Djordje Mikić. Social and Economical Occasions of Serbian people from Kosovo in XIX and at the Beginning of XX Century. Belgrade: Serbian Academy of Sciences and Arts.

Urošević 2001: Atanasije Urošević. „Dual Faith among Albanians“. About Kosovo - Anthropogeographic Studies and Other Scriptures. Prishtina-Gnjilane: Public and University Library „Ivo Andrić“, Institute for Serbian Culture, Library „Sveti Sava“, 83-92.

Urošević 2001a: Atanasije Urošević. „One New Example of Dual Faith“. About Kosovo - Anthropogeographic Studies and Other Scriptures. Prishtina-Gnjilane: Public and University Library „Ivo Andrić“, Institute for Serbian Culture, Library „Sveti Sava“, 181-183.

Stojančević 1994: Vladimir Stojančević. „Austro-Hungarian and Serbian Conflict in Kosovo Vilayet at the Beginning of XX Century“. Serbs and Albanians 1804-1912. Novi Sad: Prometej, 245-272.

Toleva 2018: Teodora Toleva. The Influence of the Austro-Hungarian Empire on the Creation of the Albanian Nation 1896-1908. Belgrade: Filip Višnjić, Institute for European Studies.

Ćorović 1992: Vladimir Ćorović. Relations Between Serbia and Austro-Hungary in XX Century. Belgrade: Library of the City of Belgrade.

Hrabak 2005: Bogumil Hrabak. „Austro-Hungarian Cult Protectorate over Catholic Albanians 1897“. Albanians Studies, book II. Belgrade: Arhivar, 243-262.

Hrabak 1998: Bogumil Hrabak. Prizren Albanian League 1878-1881. Belgrade: Author Šešum 2017: Uroš Šešum. Serbia and Old Serbia(1804-1839). Belgrade: Faculty of Philosophy. Vickers 1998: Miranda Vickers. Between Serb and Albanian. A History of Kosovo. New York: Columbia University Press. 


\section{Весна С. ЗАРКОВИТ}

\section{ФАНАЕ И АЕ ОВАҢЕ АУСТРОУГАРСКЕ У ПРИЗРЕНСКОМ И ПЕККОМ САНџАКУ (1900-1905)}

\section{РеЗИме}

Фанде су биме Арбанаси римокатоличке вере који се на просторе Старе Србије, пре свега Метохије, насељавају из северне А^баније. Заузимали су напуштена српска имања посме значајних историјских дешавања, након којих су се Срби повлачили на север. Понашање фанда у деловима Косовског вилајета показује сву комплексност политичких збивања у последњим деценијама османске власти на овим просторима. Иако припадници истог народа, са истим језиком, поделе између фанда и Арбанаса мухамеАанаца дуго су се испољавале. Фанде су се сукобљавале не само са својим сународницима, које су сматрали мање вредним због промене вере, већ и са православним хришћанима - Србима, које су, у скиаду са верском доктрином, називали шизматицима. Малобројност у односу на обе групе спречавала их је Аа јаче испоље своје ставове. Велику подршку за своје активности фанде су имале у римокатоличкој цркви, која је настојала Аа свој утицај прошири што више на исток.

Ао зближавања фанда и Арбанаса мухамеданаца дошло је највише након Берлинског конгреса. Значајну укогу у том процесу имала је Аустроугарска, која је у Арбанасима видела среАство за остварење свог циља - продора на Исток. Са фандама су делили исту религију, а Арбанасима мухамеАанцима није сметало што су преА Аустроугарима из Босне избегли многи муслимани. Аа макше дођу Ао свог циља Аустријанци су константном и упорном пропагандом градили јединство фанда и Арбанаса мухамеданаца, супротстављајући га Србима али и османској Аржави. Србе су преАставьали као главне противнике Арбанаса и турске Аржаве, због чега су на њих насртали како мухамеАанци, тако и фанде. Примери који су наведени у раду говоре о јасној спрези Аустроугарске и Арбанаса римокатолика-фанда.

Кьучне речи: Срби, Арбанаси, фанде, Аустроугарска, Пећки санџак, Призренски санџак.

РаА је преАат 25. фебруара 2020. године, а након мишьења рецензената, оАлуком одговорног уредника Башйине, одобрен за штампу. 